\title{
Effect of storage period on internal and external parameters of Deshi Chicken fowl
}

\section{Jitendra Goldie Lall, Ajeet Kumar Santra and Sambhuti Shankar Sahu*}

Department of Livestock Production Management, College of Veterinary Science and Animal Husbandry, Anjora, Chhattisgarh Kamdhenu Vishwavidyalaya, Durg (Chhattisgarh), INDIA

*Corresponding author. E-mail:Shambhutisahu1987@gmail.com

Received: May 26, 2017; Revised received: August 2, 2017; Accepted: January 7, 2018

\begin{abstract}
The fresh eggs were collected and evaluated to effect of storage periods on internal and external characteristics in local chicken eggs. The mean value of the egg weight, egg width, shape index, albumin height, albumen weight, albumen percentage, albumin index, yolk height, yolk weight, yolk percentage, yolk index, shell thickness, shell weight, shell \%, albumin $\mathrm{pH}$, albumin protein and Haugh Unit are $58.60 \pm 0.84 \mathrm{~g}, 4.08 \pm 0.02 \mathrm{~cm}, 76.39 \pm 1.02$, $5.40 \pm 0.16 \mathrm{~mm}, 33.67 \pm 0.37 \mathrm{~g}, 58.07 \pm 0.55 \%, 6.76 \pm 0.49,18.20 \pm 0.29 \mathrm{~mm}, 18.33 \pm 0.43 \mathrm{~g}, 44.27 \pm 0.91 \%, 44.27 \pm 0.91 \%$, $0.29 \pm 0.02,6.06 \pm 0.22,10.39 \pm 0.25,7.82 \pm 0.02,11.77 \pm 0.07$ and $72.63 \pm 1.34$ in local chicken eggs. The data from current study indicates that with increase in storage period, a significant $(\mathrm{P}<0.01)$ decline was observed in various parameters like percentage weight loss, albumen height, yolk height, egg width, albumen index, yolk index, Haugh unit, albumen \%, albumen weight, shell thickness and albumen protein. Contrary to this, albumen $\mathrm{pH}(\mathrm{P}<0.01)$ was found to escalate with increase in storage period. Egg length, shell \%and yolk \% have significantly differed at $(\mathrm{P}<0.01)$ level. Shape index and shell weight showed no significant differences.
\end{abstract}

Keywords: Desi fowl, Egg, Quality parameters, Storage

\section{INTRODUCTION}

The egg is one of the most nutritious as well as nonexpensivefood available to man and it provides a well balanced source of nutrients for the man of all ages (Matt et al., 2009). Poultry is one of the fastest growing segments of the agricultural sector in India with around eight percent growth rate per annum. India ranks 3 rd in egg production and 7 th in chicken meat production in the world (Watt Executive Guide, 2015). The constant efforts in upgradation, alteration and application of new technologies smooth the way for the multifold and multifaceted growth in poultry sectors. Development of high yielding layer (310- 340 eggs) and broiler (2.4-2.6 kg at $6 \mathrm{wks}$ ) varieties together with standardized package of practices on nutrition, housing, management and disease control have contributed to spectacular growth rates in egg (4-6\% per annum) and broiler production (8-10\% per annum) in India . About 3.4 million tons (74 billion) of eggs are produced from 260 million layers and 3.8 million tons of poultry meat is produced from 3000 million broilers per annum in India. The Poultry Industry is contributing about Rs.70,000/- crores to the national GDP and providing employment to more than 4 million people either directly or indirectly (Chatterjee and Rajkumar, 2015).Moreover, egg quality affects the price and fertility of eggs. During storage, eggs are extremely prone to quality deterioration and microbial contamination. Moreover, egg quality affects the price and fertility of eggs. During storage, eggs are extremely prone to quality deterioration and microbial contamination. These conditions can cause serious economic losses to the poultry industry (Wong et al., 1996). One of the constraints is to preserve the egg qualities by selecting the most efficient storage system i.e. storage type and duration. As soon as egg is laid by the hen its quality starts to deteriorate (Jin et al., 2011). Egg shell quality may be affected by the strain and age of hen; induced moult; nutritional factors such as calcium, phosphorus, vitamins, water quality, non-starch polysaccharides, enzymes, contamination of feed; general stress and heat stress; disease, production system, or addition of proprietary products to the diets. Egg internal quality may be affected by storage; hen strain and age; induced moult, nutrition and disease. An understanding of the range of factors that affect egg shell quality and egg internal quality is essential for the production of eggs of high quality (Ahmadi and Rahimi, 2011) Several chemical and physical modifications occur inside an egg during the storage period As the storage temperature and time increased, egg weight, percentage of albumen, Haugh unit (HU), and yolk color decreased but egg shell weight, shell percentage, and albumen weight, yolk $\mathrm{pH}$ increased with increasing storage time 
(Jin,2011). Easily observable physical changes include an increase in the air cell, thinning of the albumen and flattening of yolk. Therefore, the present study has been carried out to investigate the possible effects of storage period on the quality changes in chicken eggs.

\section{MATERIALS AND METHODS}

Various internal and external egg quality parameters were evaluated in relation to storage period in the present study. In excess of fresh eggs of local chickens were evaluated in the months of March, May and July. The experiment was carried out at the Livestock Production Management Department, Anjora, Durg. On arrival of fresh eggs in the laboratory, eggs were randomly divided into 3 groups: Control group, Group A and Group B. There were 6 eggs in each group and eggs were taken periodically at 7 days interval for a total duration of 21 days of storage period. The classification of groups was done as described by Sharma (1997) with some modifications. A total of 24 eggs from the control group and 18 eggs from group $\mathrm{A}$ and group $\mathrm{B}$ (18 eggs from each subgroups $\mathrm{B}_{1}, \mathrm{~B}_{2}, \mathrm{~B}_{3}$ and B4) were used during the study period. The Group A comprising 22 eggs were stored in a refrigerator at $5^{\circ}$ C. The Group B comprising (72 eggs) were kept at the room temperature and further $\mathrm{B}_{1}, \mathrm{~B}_{2}, \mathrm{~B}_{3}$, and $\mathrm{B}_{4}$ divided into four subgroups having an equal number of eggs. The $\mathrm{B}_{1}$ group were kept in the earthen pot without any treatment while the $\mathrm{B}_{2}$ group was treated by refined rice bran oil, the $B_{3}$ group were treated by lime and $\mathrm{B}_{4}$ group was treated by thermo stabilisation as per the procedure described by Sharma (1997). Briefly, eggs were immersed in hot water at $130.0^{\circ} \mathrm{F}$ for 15 minutes. This heating process stabilized the thick portion of albumen reducing the evaporation of moisture from internal parts of eggs, thereby retaining their fresh appearance for longer period. Rest of the eggs in each groups were considered as replicates in case of any undesirable damage to the egg during the study period. The following parameters viz egg weight, weight loss \%, egg width, egg length, shape index, albumen height, albumen weight, albumen \%, albumen index, yolk height, yolk weight, yolk \%, yolk index, shell thickness, shell weight, shell \%, albumen $\mathrm{pH}$, albumen protein and Haugh Unit. Characterising egg quality were analysed during the study periods in month of March May and July.

\section{RESULTS AND DISCUSSION}

The fresh eggs were collected and evaluated to compare the mean value of internal and external characteristics in local chicken eggs. The mean values of external and internal parameters of the fresh eggs are shown in Table 1, 2 and 3. Our study revealed that egg weight was significantly increased $(\mathrm{P}<0.01)$ at different storage periods. Our results are not in agreement with those of Samli et al. (2005) who reported weight reductions of 2.08 and $3.11 \%$ respectively with in 5 and 10 days of storage periods. The increase in egg weight may be due to liquefaction of egg proteins.

The overall mean value of albumen height was observed to differ significantly $(\mathrm{P}<0.01)$ with storage period. The overall albumen $\%$ recorded at different time points were: day $1(58.07 \pm 0.06 \%), 7$ days, $(59.99 \pm 0.05 \%), 14$ days $(58.61 \pm 0.04 \%)$ and 21 days $(59.71 \pm 0.07 \%)$ of storage period. There was significant effect $(\mathrm{P}<0.01)$ of storage period on albumen $\%$. Our results are in corroborating with the findings of Jin et al. (2011) who reported similar findings of albumen height and albumen percentage.

No particular pattern was observed in albumen weight with storage time. The mean value of albumen weight of $33.67 \mathrm{~g}, 37.12 \mathrm{~g}, 35.35 \mathrm{~g}$ and $35.83 \mathrm{~g}$ at $0,7,14$ and 21 days of storage periods, respectively. These results are in agreements with Tabidi (2011) and Tayeb (2012).

In the present study, albumen index was found to decrease $(p<0.01)$ significantly with increase in storage period. The present findings collaborates the reports of Tabidi (2011).Water loss from the egg or movement of water from albumin to yolk may be the possible cause of this result.

The present study indicated a significant decreases $(p<0.01)$ in weight of yolk with increased storage time. The significant $(\mathrm{P}<0.01)$ decrease in yolk index was also observed with increasing storage period. The decline in aforesaid parameters may be due to gradual weakening of the vitelline membrane, reduction of the total solid and liquefaction of the yolk index.

The shell weight was found to decrease nonsignificantly with storage period. Akyurek and Okur (2009) and Jin et al (2011) also reported a significant decline in shell weight with increase in storage period. Albumen $\mathrm{pH}$ was found to escalate significantly $(\mathrm{P}<0.01)$ with increasing storage period. The present

Table 1. Effect (Mean \pm SE) of storage period on the external egg characteristics.

\begin{tabular}{lllllll}
\hline DAYS & EWB $(\mathbf{g})$ & EWA $(\mathbf{g})$ & WL $\mathbf{( \% )}$ & EWD $(\mathbf{c m})$ & EL $(\mathbf{c m})$ & SI $(\%)$ \\
\hline Day $\mathbf{1}$ & $58.05 \pm 0.36^{\mathbf{a}}$ & $58.05 \pm 0.54^{\mathbf{a}}$ & $0.00 \pm 0.00^{\mathbf{a}}$ & $4.08 \pm 0.37^{\mathbf{a}}$ & $5.35 \pm 0.06^{\mathbf{b}}$ & $76.39 \pm 0.72$ \\
$\mathbf{7}$ & $62.48 \pm 0.24^{\mathbf{b}}$ & $61.78 \pm 0.23^{\mathbf{c}}$ & $1.25 \pm 0.24^{\mathbf{b}}$ & $4.14 \pm 0.54^{\mathbf{b}}$ & $5.44 \pm 0.04^{\mathbf{c}}$ & $76.34 \pm 0.45$ \\
$\mathbf{1 4}$ & $62.33 \pm 0.43^{\mathbf{b}}$ & $60.28 \pm 0.68^{\mathbf{b}}$ & $3.23 \pm 0.56^{\mathbf{c}}$ & $4.10 \pm 0.41^{\mathbf{a}}$ & $5.28 \pm 0.05^{\mathbf{a}}$ & $77.23 \pm 0.53$ \\
$\mathbf{2 1}$ & $63.33 \pm 0.54^{\mathbf{b}}$ & $59.94 \pm 0.43^{\mathbf{b}}$ & $5.26 \pm 0.74^{\mathbf{d}}$ & $4.09 \pm 0.23^{\mathbf{a}}$ & $5.36 \pm 0.07^{\mathbf{b}}$ & $76.23 \pm 0.24$ \\
Level of sign. & $* *$ & $* *$ & $* *$ & $*$ & $* *$ & NS \\
\hline
\end{tabular}

Values (Mean $\pm \mathrm{SE}$ ) with different superscripts in a row differ significantly $* \mathrm{p}<0.05, * * \mathrm{p}<0.01 ; \mathrm{NS}=$ Non-significant. $\mathrm{EW}=\mathrm{Egg}$ Weight, $\mathrm{WL}=$ Percent egg weight loss, EWD= Egg Width, EL=Egg Length, SI= Shape Index. 
Jitendra Goldie Lall et al. / J. Appl. \& Nat. Sci. 10 (1): 41 - 44 (2018)

Table 2. Effect (Mean $\pm \mathrm{SE}$ ) of storage period on the internal egg characteristics.

\begin{tabular}{|c|c|c|c|c|c|c|c|c|}
\hline DAYS & $\mathbf{A H}(\mathbf{m m})$ & AW (g) & AWP (\%) & AI (\%) & YH (mm) & YW (g) & YWP (\%) & YI (\%) \\
\hline$\overline{D a y} 1$ & $5.40 \pm 0.02^{\mathrm{a}}$ & $33.67 \pm 0.04^{\mathrm{a}}$ & $58.07 \pm 0.06^{\mathrm{a}}$ & $6.76 \pm 0.05^{\mathrm{a}}$ & $18.19 \pm 0.02^{\mathrm{a}}$ & $18.33 \pm 0.04^{\mathrm{a}}$ & $31.53 \pm 0.05^{\mathrm{a}}$ & $44.27 \pm 0.06^{\mathrm{a}}$ \\
\hline 7 & $4.50 \pm 0.04^{b}$ & $37.12 \pm 0.07^{\mathfrak{c}}$ & $59.99 \pm 0.05^{\mathbf{b}}$ & $5.41 \pm 0.04^{\mathrm{b}}$ & $15.38 \pm 0.06^{\mathbf{b}}$ & $18.76 \pm 0.03^{b}$ & $30.37 \pm 0.04^{\mathbf{b}}$ & $34.57 \pm 0.15^{\mathbf{b}}$ \\
\hline 14 & $3.53 \pm 0.03^{\mathrm{c}}$ & $35.35 \pm 0.09^{\mathbf{b}}$ & $58.61 \pm 0.04^{\mathrm{a}}$ & $3.96 \pm 0.04^{\mathfrak{c}}$ & $12.89 \pm 0.07^{\mathbf{c}}$ & $19.08 \pm 0.04^{b}$ & $31.67 \pm 0.05^{\mathrm{a}}$ & $26.85 \pm 0.21^{\mathrm{c}}$ \\
\hline 21 & $2.93 \pm 0.03^{\mathrm{d}}$ & $35.83 \pm 0.11^{\mathbf{b}}$ & $59.71 \pm 0.07^{\mathbf{b}}$ & $3.28 \pm 0.04^{\mathrm{d}}$ & $10.85 \pm 0.07^{\mathrm{d}}$ & $18.23 \pm 0.04^{\mathrm{a}}$ & $30.46 \pm 0.06^{\mathbf{b}}$ & $22.32 \pm 0.22^{\mathrm{d}}$ \\
\hline Level of sign. & $* *$ & $* *$ & $* *$ & $* *$ & $* *$ & $* *$ & $* *$ & $* *$ \\
\hline
\end{tabular}

Values (Mean \pm SE) with different superscripts in a row differ significantly ${ }^{*} \mathrm{p}<0.05,{ }^{*} \mathrm{p}<0.01$; NS $=$ Non-significant. $\mathrm{AH}=\mathrm{Al}-$ bumen Height, $\mathrm{AW}=$ Albumen Weight, $\mathrm{AWP}=$ Albumen \%, AI = Albumen Index, $\mathrm{YH}=$ Yolk Height, $\mathrm{YW}=\mathrm{Yolk}$ Weight, $\mathrm{YWP}=$ Yolk \%, YI=Yolk Index.

Table 3. Effect $( \pm \mathrm{SE})$ of storage period on the internal egg characteristics.

\begin{tabular}{lcccccc}
\hline DAYS & ST $(\mathbf{m m})$ & SW $(\mathbf{g})$ & SWP $(\%)$ & APH & AP (\%) & HU \\
\hline Day 1 & $0.29 \pm 0.003^{\mathbf{a}}$ & $6.06 \pm 0.02$ & $10.39 \pm 0.02^{\mathbf{a}}$ & $7.81 \pm 0.01^{\mathbf{a}}$ & $11.77 \pm 0.05^{\mathbf{a b}}$ & $72.64 \pm 0.15^{\mathbf{a}}$ \\
7 & $0.32 \pm 0.008^{\mathbf{b}}$ & $5.92 \pm 0.02$ & $9.57 \pm 0.02^{\mathbf{b}}$ & $8.25 \pm 0.04^{\mathbf{b}}$ & $11.88 \pm 0.02^{\mathbf{a}}$ & $62.52 \pm 0.22^{\mathbf{b}}$ \\
14 & $0.34 \pm 0.004^{\mathbf{c}}$ & $5.89 \pm 0.01$ & $9.78 \pm 0.02^{\mathbf{b}}$ & $8.42 \pm 0.05^{\mathbf{c}}$ & $11.62 \pm 0.02^{\mathbf{b c}}$ & $51.55 \pm 0.30^{\mathbf{c}}$ \\
21 & $0.33 \pm 0.010^{\mathbf{c}}$ & $5.86 \pm 0.02$ & $9.78 \pm 0.03^{\mathbf{b}}$ & $8.63 \pm 0.07^{\mathbf{d}}$ & $11.44 \pm 0.03^{\mathbf{c}}$ & $41.73 \pm 0.38^{\mathbf{d}}$ \\
Level of sign. & $* *$ & NS & $* *$ & $* *$ & $* *$ & $* *$ \\
\hline
\end{tabular}

Values (Mean $\pm \mathrm{SE}$ ) with different superscripts in a row differ significantly ${ }^{*} \mathrm{p}<0.05,{ }^{*} \mathrm{p}<0.01$; NS $=$ Non-significant. $\mathrm{ST}=\mathrm{Shell}$ Thickness, $\mathrm{SW}=$ Shell Weight, $\mathrm{SWP}=$ Shell\%, APH= Albumen $\mathrm{pH}, \mathrm{AP}=\mathrm{Albumen}$ Protein $\%$, HU= Haugh Unit.

findings are in agreement with results reported by (Samli et al., 2005, Akyrek and Okur, 2009). During storage, $\mathrm{CO}_{2}$ escapes via eggshell pores resulting increase albumen pH up to 9.6-9.7 (Kemps et al., 2007). Moreover, as the egg ages, $\mathrm{CO}_{2}$ is gradually lost through the shell and the contents of the egg become more alkaline (Okeudo et al., 2003). Silversides et al. (1993) observed that $\mathrm{pH}$ is a useful means for describing changes in albumen quality over time during storage.

There were significant decrease $(\mathrm{P}<0.01)$ in $\mathrm{HU}$ with storage period. Samli et al. (2005) also documented that the storage period and temperature adversely affects HU. Tabidi (2011) and Khan et al. (2014) found that HU values decreased significantly with increase storage period. Moisture loss by evaporation through the shell pores and the escape of $\mathrm{CO}_{2}$ from albumen is important factor for the changes occur in of $\mathrm{HU}$, albumen height, albumen $\mathrm{pH}$, yolk index, specific gravity, and air cell size in egg quality (Robinson, 1987).

\section{Conclusion}

In conclusion, our study showed that storage period negatively affects the myriad quality parameters of eggs. Among various methods used, refrigeration $\left(5^{\circ} \mathrm{C}\right)$ may be effectively used to avert the deterioration of egg quality with passage of time. However, in future more in depth studies may be done to explore innovative methods that can prevent the loss of quality of eggs.

\section{REFERENCES}

Ahmadi, F. and Rahimi, F. (2011). Factors Affecting Quality and Quantity of Egg Production in Laying Hens: A
Review. World Appl. Sci. J.12 (3): 372-384

Akyurek, H. and Okur, A. (2009). Effect of storage time, temperature and hen age on egg quality in free-range layer hens.J. Anim. Vet. Adv., 8: 1953-1958

Jin, Y.H., Lee, K.T., Lee, W.I. and Han, Y.K. (2011). Effects of storage temperature and time on the quality of eggs from laying hens at peak production. Asian- Aust. J. Anim. Sci.,24 (2): 279-284

Kemps, B. J., De Ketelaere, B., Bamelis, F. R., Mertens, K., Decuypere, E. M., De Baerdemaeker, J. G. and Schwagele, F. (2007). Albumen freshness assessment by ombining visible near-infrared transmission and lowresolution proton nuclear magnetic resonance spectroscopy.Poult. Sci.,86:752-9

Khan, M. J. A., Khan, S.H., Bukhsh, A., and Amin, A. (2014). The effect of storage time on egg quality and hatchability characteristics of Rhode Island vet. arhiv, 84 (3): 291-303

Matt, D., Veromann, E. and Luik, A. (2009). Effect of housing systems on biochemical composition of chicken eggs. Agron. Res., 7:662-667

Okeudo, N.J., Onwuchekwa, C.I. and Okoli, I.C. (2003). Effect of oil treatment and length of storage on the internal quality, organoleptic attributes and microbial profile of chicken egg.Tro. Anim. Prod. Investigations, 6: $63-70$

Chatterjee, R.N. and Rajkumar, U. (2015). An overview of poultry production in India. Indian J. Anim. Hlth. , 54 (2) : 89-108

Robinson, D. S. (1987). The chemical basis of albumen quality. In egg quality- current problems and recent advances (Ed. R. G. Wells and C. G. Belyavin). Butterworths, Landon. pp: 179-191.

Samli, H.E.,Agma, A. and Senkoylu, N. (2005). Effect of storage time and temperature on egg quality in old laying hens. J. Appl. Poult. Res., 14: 548-553

Sharma, D. (1997). Preservation of desi fowl eggs at room temperature in different seasons. Ind. J. Poult. Sci.,32 (1): 102-105. 
Jitendra Goldie Lall et al. / J. Appl. \& Nat. Sci. 10 (1): 41 - 44 (2018)

Tabidi, M. H. (2011). Impact of storage period and quality on composition of table egg. Adv. Environ. Biol., 5 (5): $856-861$

Tayeb, T.I. (2012). Effects of storage temperature and length on egg quality parameters of laying hen. J. Ani. Sci., 1 (2): $32-36$

Watt Executive Guide (2015). Poultry Trends. Retrieved from www.wattagnet.com
Silversides F. G., Twizeyimana, F. and Villeneuve, P. (1993). Research note: A study relating to the validity of the Haugh unit correction for egg weight in fresh eggs. Poult. Sci., 72: 760-764.

Wong, Y.C., Herald, T. J. and Hachmeister, K.A. (1996). Evaluation of mechanical and barrier properties of protein coatings on shell eggs. Poult Sci.,75: 417-22 